\title{
Erratum
}

\section{Reconstructing North Sea palaeolandscapes from 3D and high-density 2D seismic data: An overview - ERRATUM}

\section{S. van Heteren, J.A.C. Meekes, M.A.J. Bakker, V. Gaffney, S. Fitch, B.R. Gearey \& B.F. Paap}

doi: 10.1017/njg.2014.4, Published by Cambridge University Press, 13 March 2014.

Keywords: geoarchaeology, the Netherlands, Quaternary, sea-level change, erratum

The article by van Heteren (first published online 13 March 2014) contained an error in the affiliation list. The correct author and affiliation list is republished here.

S. van Heteren ${ }^{1}$, J.A.C. Meekes ${ }^{2}$, M.A.J. Bakker ${ }^{1}$, V. Gaffney ${ }^{3}$, S. Fitch ${ }^{3, \dagger}$, B.R. Gearey ${ }^{3, \ddagger} \&$ B.F. Paap ${ }^{2}$

1 TN0- Geological Survey of the Netherlands, P0 Box 80015, NL-3508 TA Utrecht, the Netherlands

2 TN0- Sustainable Geo-Energy, P0 Box 80015, NL-3508 TA Utrecht, the Netherlands

3 IBM Visual and Spatial Technologies Centre, University of Birmingham, Edgbaston B15 2TT, United Kingdom
† Present address: 94 Coniston Road, Leamington Spa, Warwickshire, CV32 6PF, United Kingdom

‡ Present address: Department of Archaeology, Connolly Building, Dyke Parade, University College Cork, Cork City, Ireland

\section{Reference}

van Heteren, S., Meekes, J.A.C., Bakker, M.A.J., Gaffney, V., Fitch, S., Gearey, B.R. \& Paap, B.F., Reconstructing North Sea palaeolandscapes from 3D and high-density 2D seismic data: An overview. Netherlands Journal of Geosciences. First published online: 13 March 2014, doi: 10.1017/njg.2014.4. 